\title{
Uji Konsentrasi Hambat Minimum (KHM) Getah Kulit Buah Pisang Goroho (Musa acuminafe L.) terhadap Pertumbuhan Staphylococcus aureus
}

\author{
${ }^{1}$ Kleysia D. Wuon \\ ${ }^{2}$ Damajanty H. C. Pangemanan \\ ${ }^{1}$ P. S. Anindita
}

\author{
${ }^{1}$ Program Studi Pendidikan Dokter Gigi Fakultas Kedokteran \\ ${ }^{2}$ Bagian Fisiologi Fakultas Kedokteran \\ Universitas Sam Ratulangi Manado \\ Email: kleysiawuon@gmail.com
}

\begin{abstract}
Staphylococcus aureus is the most dominant cause of odontogenuic abscess, albeit, it is resistant to various types of antibiotics. The sap of goroho banana peel (Musa acuminafe L.) contains antibacteria compounds inter alia flavonoid, saponin, and tannin. This study was aimed to determine the minimal inhibitory concentration (MIC) of the sap of goroho banana peel to the growth of Staphylococcus aureus. This was a true experimental study with a randomized pretest-posttest control group design. We used serial dilution with turbidimetry and spectrophotometry as the test methods. Goroho banana was taken from Kelurahan Winangun, Kecamatan Malalayang meanwhile S. aureus bacteria were obtained from Microbiology Laboratory of Pharmacy Study Program, Faculty of Mathematics and Natural Sciences, Sam Ratulangi University. The result of turbidimetry after incubation showed that the tube of $50 \%$ of goroho sap looked clear. Measuring absorbance values before and after incubation using spectrophotometer UV-Vis showed that the MIC of the goroho sap was at 25\%. Conclusion: The MIC of the sap of goroho banana peel (Musa acuminafe L.) to the growth of Staphylococcus aureus was at concentration of $25 \%$.
\end{abstract}

Keywords: sap of goroho banana peel (Musa acuminafe L.), S. aureus, MIC

\begin{abstract}
Abstrak: Staphylococcus aureus merupakan bakteri penyebab abses odontogenik yang paling dominan. Saat ini $S$. aureus telah resisten terhadap berbagai jenis antibiotik. Getah kulit buah pisang goroho (Musa acuminafe L.) merupakan tanaman herbal yang mengandung senyawa antibakteri, yaitu flavonoid, saponin, dan tanin. Penelitian ini bertujuan untuk mengetahui konsentrasi hambat minimum (KHM) getah kulit buah pisang goroho terhadap pertumbuhan $S$. aureus. Jenis penelitian ialah eksperimental murni dengan randomized pretest-posttest control group design. Metode yang digunakan yaitu metode serial dilusi dengan pengujian turbidmetri dan spektrofotometer. Pisang goroho diperoleh dari Kelurahan Winangun, Kecamatan Malalayang. Bakteri S. aureus diambil dari stok bakteri murni Laboratorium Mikrobiologi Program Studi Farmasi Fakultas MIPA Universitas Sam Ratulangi. Hasil penelitian turbidmetri sesudah inkubasi menunjukkan bahwa tabung dengan konsentrasi getah kulit buah pisang goroho $50 \%$ terlihat mulai jernih. Pengukuran nilai absorbansi sebelum dan sesudah inkubasi menggunakan spektrofotometer UV-Vis menunjukkan bahwa KHM getah kulit buah pisang goroho (Musa acuminafe L.) terhadap pertumbuhan bakteri S. aureus terdapat pada konsentrasi $25 \%$. Simpulan: Konsentrasi hambat minimum getah kulit buah pisang goroho (Musa acuminafe L.) terhadap pertumbuhan bakteri S. aureus terdapat pada konsentrasi 25\%
\end{abstract}

Kata kunci: getah kulit buah pisang goroho (M. acuminafe), S. aureus, KHM 
Rongga mulut yang tidak terjaga kebersihannya dapat memicu terjadi infeksi, yang tersering terjadi yaitu abses odontogenik. ${ }^{1}$ Bakteri penyebab abses odontogenik yang paling dominan yaitu Staphylococcus aureus. ${ }^{2}$ Antibiotik golongan penisilin sering digunakan dalam menangani infeksi yang disebabkan oleh $S$. aureus, namun bakteri tersebut telah resisten terhadap antibiotik golongan penisilin termasuk methicillin sehingga disebut sebagai Methicillin-Resistant Staphylococcus aureus (MRSA). Prevalensi MRSA di Asia cukup tinggi yaitu mencapai $70 \%$ dan di Indonesia mencapai $23,5 \%$ pada tahun $2006 .{ }^{3}$ Resistensi disebabkan adanya gen mecA yang digunakan untuk mengkode protein pengikat dengan afinitas rendah. ${ }^{4}$

Salah satu tumbuhan herbal yang mudah ditemukan di Provinsi Sulawesi Utara yaitu buah pisang goroho (Musa acuminafe L) yang sering dijadikan kripik, direbus, atau digoreng. ${ }^{5}$ Penggunaan pisang goroho sebagai tanaman herbal pada masyarakat provinsi Sulawesi Utara sejak jaman nenek moyang dahulu. Pisang goroho sering tumbuh di samping rumah, di pingiran kebun dan juga yang dikembangbiakkan. Salah satu bagian dari tanaman buah pisang goroho yang dapat dijadikan obat yaitu getahnya. ${ }^{5.6}$

Getah kulit buah pisang goroho memiliki kandungan fitokimia seperti flavonoid, tannin, dan saponin. ${ }^{7}$ Flavonoid ialah golongan terbesar dari senyawa fenol yang dapat menghambat pertumbuhan bakteri. Flavonoid memiliki manfaat sebagai anti radang, meningkatkan efektivitas vitamin C, melindungi struktur sel, dan sebagai antibiotik. $^{8}$ Saponin merupakan glukosida yang larut dalam air dan banyak ditemukan pada makanan yang memiliki berat molekul tinggi. Saponin dapat mengganggu stabilitas membran sel bakteri sehingga sel bakteri menjadi lisis. Tanin memiliki khasiat sebagai anti diare, anti bakteri, dan antioksidan. $^{8.9}$

Penelitian yang dilakukan oleh Rante et al. ${ }^{6}$ membuktikan bahwa getah kulit buah pisang goroho dengan konsentrasi $100 \%$ memiliki efek antibakteri terhadap Staphylococcus aureus, namun belum melaporkan Konsentrasi Hambat Minimum (KHM) getah kulit buah pisang goroho.

Penelitian ini bertujuan untuk mengetahui KHM getah kulit buah pisang goroho sebagai antibakteri terhadap Staphylococcus aureus.

\section{BAHAN DAN METODE PENELITIAN}

Jenis penelitian ini ialah eksperimental murni (true experimental design) dengan rancangan penelitian randomized pretestposttest control group design. Penelitian dilaksanakan di Laboratorium Farmasi Program Studi Farmasi Fakultas MIPA Universitas Sam Ratulangi Manado dari bulan April - Mei 2018. Subjek dalam penelitian ini yaitu bakteri biakan murni Staphylococcus aureus yang diperoleh dari Laboratorium Mikrobiologi Program Studi Farmasi Fakultas MIPA Universitas Sam Ratulangi Manado.

Pisang goroho diambil dari kelurahan Winangun, Kecamatan Malalayang, Kota Manado, Sulawesi Utara. Pengambilan getah kulit buah pisang goroho dilakukan di Laboratorium Farmasi Fakultas MIPA Universitas Sam Ratulangi Manado. Kulit buah pisang goroho dipotong pangkal buahnya satu persatu kemudian dibiarkan getahnya menetes selama 5 menit dan ditampung sebanyak $10 \mathrm{ml}$ ke dalam wadah kaca steril. Setelah itu dilakukan pemisahan senyawa getah kulit buah pisang goroho dengan Kromatografi Lapis Tipis (KLT) analitik mengunakan plat silika gel GF254.

Metode penelitian yang digunakan yaitu serial dilusi (pengenceran bertingkat) dengan perbandingan 1:2 (w/v). Metode pengujian dengan menggunakan turbidmetri dan diukur nilai absorbansi atau nilai kekeruhan menggunakan spektrofotometer UV-Vis.

Bakteri yang telah diremajakan pada media agar miring, diambil koloninya dengan menggunakan jarum ose steril, kemudian koloni dimasukkan ke media BHI-B dalam tabung reaksi dan diinkubasi pada suhu $37^{\circ} \mathrm{C}$ selama 1 x 24 jam. Setelah diinkubasi, dilakukan pembuatan suspensi 
S. aureus sesuai dengan standar kekeruhan McFarland 1. Sebanyak 11 tabung reaksi steril disiapkan. Setiap tabung uji diberi label 1-9, kemudian tabung 10 diberi label $\mathrm{K}(+)$ yang merupakan kontrol positif, yaitu tabung berisi Staphylococcus aureus setara dengan kekeruhan McFarland 1. Tabung 11 diberi label $\mathrm{K}(-)$ yang merupakan kontrol negatif, yaitu tabung yang berisi getah kulit buah pisang goroho dengan konsentrasi $100 \%$. Tabung 1 diisi sebanyak $4 \mathrm{ml}$ konsentrasi $100 \%$ getah kulit buah pisang goroho. Tabung 2 - 9 diisi dengan 2 ml media cair BHI. Kemudian di ambil 2 $\mathrm{ml}$ larutan dari tabung 1, dimasukkan kedalam tabung 2, dicampur hingga homogen sehingga didapatkan konsentrasi $50 \%$. Hal yang sama dilakukan sampai tabung 9 sehingga didapatkan semua konsentrasi getah kulit buah pisang goroho dengan perbandingan 1:2(w/v).

Untuk menguji kekeruhan, diambil media suspensi bakteri yang sudah disetarakan dengan standar kekeruhan McFarland 1 sebanyak $0,5 \mathrm{ml}$, kemudian dimasukkan kedalam tabung reaksi perlakuan label 1 lalu diukur nilai absorban awal dengan spektrofotometer. Hal yang sama dilakukan pada tabung perlakuan label 2-9. Setiap tabung yang telah diketahui nilai absorbansi awal kemudian dimasukkan kedalam inkubator dan diinkubasi pada suhu $37^{\circ} \mathrm{C}$ selama 1 x 24 jam. Pada penelitian ini, perlakuan dan pengujian diulang sebanyak tiga kali. Setelah media tabung perlakuan diinkubasi selama 1x24 jam, semua tabung tersebut dilihat kekeruhannya secara visual. Bila kekeruhan masing-masing tabung masih setara atau lebih keruh dari tabung $\mathrm{K}$ (+) yang berisi suspensi bakteri $S$. aureus sesuai standar kekeruhan McFarland 1 berarti bakteri masih dapat bertumbuh, tetapi ketika larutan dalam tabung terlihat mulai lebih jernih daripada tabung $\mathrm{K}(+)$ berarti pertumbuhan bakteri mulai terhambat. Hal inilah yang menunjukkan KHM. Semua tabung perlakuan diukur nilai absorbansinya dengan spektrofotometer sebagai nilai absorbansi akhir. Jika nilai absorbansi akhir (sesudah inkubasi) masing-masing tabung lebih besar dari nilai absorbansi awal (sebelum inkubasi), maka disimpulkan bahwa masih terjadi pertumbuhan bakteri. Namun, jika sebaliknya tidak terdapat perubahan nilai absorbansi antara nilai absorbansi awal dan nilai absorbansi akhir, atau nilai absorbansi akhir lebih kecil dari nilai absorbansi awal, maka disimpulkan bahwa pertumbuhan bakteri dihambat. Konsentrasi Hambat Minimum (KHM) ditentukan dengan konsentrasi terkecil pada tabung perlakuan yang sudah mulai menghambat pertumbuhan bakteri S. aureus.

\section{HASIL PENELITIAN}

Penelitian ini dilakukan di Laboratorium Mikrobiologi Program Studi Farmasi Fakultas MIPA Universitas Sam Ratulangi. Hasil pengujian turbidimetri menujukan bahwa tabung yang berisi getah kulit buah pisang goroho dengan konsentrasi $50 \%$ terlihat mulai jernih. Hal ini berarti bahwa konsentrasi 50\% merupakan KHM getah kulit buah pisang goroho dalam menghambat pertumbuhan bakteri $S$. aureus. Hasil turbidimetri dapat dilihat pada Tabel 1.

Tabel 1. Hasil uji KHM getah kulit buah pisang goroho terhadap pertumbuhan bakteri $S$. aureus pada perlakuan pertama sampai perlakuan ketiga dengan metode turbidimetri

\begin{tabular}{cccc}
\hline $\begin{array}{c}\text { Konsentrasi getah kulit } \\
\text { buah pisang goroho }\end{array}$ & I & II & III \\
\hline 100 & - & - & - \\
50 & - & - & - \\
25 & + & + & + \\
12,5 & + & + & + \\
6,25 & + & + & + \\
3,125 & + & + & + \\
1,56 & + & + & + \\
0,78 & + & + & + \\
0,39 & + & + & + \\
$\mathrm{K}(+)$ & + & + & + \\
$\mathrm{K}(-)$ & - & - & - \\
\hline
\end{tabular}

Keterangan: Tanda (+), cairan di dalam tabung terlihat keruh yang berarti bakteri $S$. aureus masih memiliki kemampuan untuk bertumbuh. Tanda (-), cairan di dalam tabung mulai berkurang kekeruhannya yang berarti pertumbuhan bakteri $S$. aureus mulai terhambat. $\mathrm{K}(+)$ kontrol positif yang berisi suspensi bakteri setara McFarland. K(-) kontrol negatif yang berisi getah kulit buah pisang goroho dengan konsentrasi $100 \%$. 
Penelitian dilanjutkan dengan pengujian melalui pengukuran nilai absorbansi menggunakan spektrofotometer UV-Vis untuk mendapatkan hasil pengukuran kekeruhan secara kuantitatif. Nilai absorbansi merupakan nilai yang menunjukkan besarnya jumlah cahaya yang diserap oleh larutan yang terdapat di dalam masingmasing tabung. Pengukuran nilai absorbansi dilakukan pada tabung 1 hingga 9, kontrol negatif dan positif sebelum dan sesudah inkubasi 1 × 24 jam untuk melihat selisih nilai absorbansi. Panjang gelombang yang digunakan alah $600 \mathrm{~nm}$ sesuai dengan panjang gelombang sinar tampak. Hasil pengukuran menggunakan spektrofotometer UV-Vis ditampilkan pada Tabel 2.

Tabel 2 memperlihatkan bahwa pada konsentrasi $100 \%$ terjadi penurunan nilai absorbansi yang berarti pertumbuhan bakteri terhambat. Pada konsentrasi 25\% nilai absorbansi sebelum inkubasi sama dengan nilai absorbansi sesudah inkubasi, baik pada perlakuan pertama maupun perlakuan kedua dan ketiga. Hal ini berarti bahwa berdasarkan hasil spektrofotometer UV-Vis konsentrasi 25\% merupakan KHM getah kulit buah pisang goroho terhadap pertumbuhan bakteri $S$. aureus.

Tabel 2. Hasil spektrofotometer getah kulit buah pisang goroho terhadap pertumbuhan bakteri $S$. aureus.

\begin{tabular}{|c|c|c|c|c|c|c|c|c|c|c|}
\hline \multirow[t]{3}{*}{ No } & \multirow[t]{3}{*}{ Konsentrasi } & \multicolumn{6}{|c|}{ Has i l } & \multicolumn{2}{|c|}{ Rerata } & \multirow[t]{3}{*}{ Ket } \\
\hline & & \multicolumn{3}{|c|}{ Sebelum inkubasi } & \multicolumn{3}{|c|}{ Sesudah inkubasi } & \multirow{2}{*}{$\begin{array}{l}\text { Sebelum } \\
\text { inkubasi }\end{array}$} & \multirow{2}{*}{$\begin{array}{l}\text { Sesudah } \\
\text { inkubasi }\end{array}$} & \\
\hline & & $\mathrm{P} 1$ & $\mathrm{P} 2$ & P3 & $\mathrm{P} 1$ & $\mathrm{P} 2$ & P3 & & & \\
\hline 1 & 100 & 0,705 & 0,879 & 0,851 & 0,622 & 0,121 & 0,682 & 0,811 & 0,475 & turun \\
\hline 2 & 50 & 0,450 & 0,546 & 0,568 & 0,833 & 0,966 & 0,964 & 0,521 & 0,921 & naik \\
\hline 3 & 25 & 0,846 & 0,846 & 0,846 & 0,846 & 0,846 & 0,846 & 0,846 & 0,846 & tetap \\
\hline 4 & 12,5 & 0,345 & 0,389 & 0,389 & 0,979 & 0,991 & 0,984 & 0,381 & 0,984 & naik \\
\hline 5 & 6,25 & 0,336 & 0,339 & 0,339 & 0,825 & 0,956 & 0,973 & 0,345 & 0,918 & naik \\
\hline 6 & 3,125 & 0,315 & 0,344 & 0,344 & 1,037 & 1,037 & 1,029 & 0,337 & 1,034 & naik \\
\hline 7 & 1,56 & 0,375 & 0,343 & 0,343 & 0,917 & 1,059 & 1,253 & 0,371 & 1,076 & naik \\
\hline 8 & 0,78 & 0,360 & 0,669 & 0,669 & 0,892 & 1,078 & 1,329 & 0,487 & 1,099 & naik \\
\hline 9 & 0,39 & 0,445 & 0,711 & 0,711 & 1,103 & 1,101 & 1,208 & 0,532 & 1,137 & naik \\
\hline 10 & $\mathrm{~K}(+)$ & 0,671 & 0,269 & 0,269 & 0,851 & 1,123 & 1,404 & 0,515 & 1,126 & naik \\
\hline 11 & $\mathrm{~K}(-)$ & 0,122 & 0,087 & 0,087 & 0,876 & 1,017 & 0,844 & 0,102 & 0,912 & naik \\
\hline
\end{tabular}

Keterangan: "Naik" menunjukkan nilai absorbansi sesudah inkubasi >nilai absorbansi sebelum inkubasi yang berarti bahwa terdapat pertumbuhan bakteri; sedangkan "Tetap" dan "Turun" menunjukkan nilai absorbansi sesudah inkubasi $\leq$ nilai absorbansi sebelum inkubasi, yang berarti bahwa pertumbuhan bakteri terhambat.

\section{BAHASAN}

Pada penelitian ini dilakukan uji KHM getah kulit buah pisang goroho terhadap pertumbuhan bakteri $S$. aureus menggunakan pengenceran bertingkat atau serial dilusi dengan perbandingan 1:2(w/v) yaitu $100 \%, 50 \%, 25 \%, 12,5 \%, 6,25 \%, 3,125 \%$, $1,56 \%, 0,78 \%$ dan $0,39 \%$. Penelitian ini diuji secara turbidimetri dan melakukan pengukuran absorbansi (nilai kekeruhan) dengan spektrofotometer UV-Vis. ${ }^{10}$ Hasil penelitian ini menunjukkan bahwa melalui pengujian turbidimetri setelah inkubasi $1 \mathrm{x}$ 24 jam pada tabung perlakuan pertama, kedua dan ketiga KHM getah kulit buah pisang goroho terhadap pertumbuhan $S$. aureus yaitu pada konsentrasi $50 \%$.

Pada metode turbidimetri dilakukan pengamatan secara visual untuk menentukan KHM, namun metode ini memiliki kelemahan yaitu subjektivitas dari masingmasing individu sehingga dapat menimbulkan kesalahan pada saat melakukan pengamatan kekeruhan; tidak dapat membedakan 
antara sel bakteri yang masih hidup dan sel bakteri yang sudah mati; dan juga dipengaruhi oleh pencahayaan di dalam ruangan penelitian. Dengan adanya keterbatasan menggunakan metode turbidimetri, maka perlu dilakukan pengujian lebih lanjut dengan mengukur nilai absorbansi menggunakan spektrofotometer UV-Vis. ${ }^{11.12}$

Pengukuran nilai absorbansi menggunakan spektrofotometer UV-Vis dilakukan sebelum dan sesudah inkubasi 1 x 24 jam untuk mendapatkan KHM yang disimpulkan dari selisih hasil pengukuran nilai absorbansi akhir (sesudah inkubasi) dengan nilai absorbansi awal (sebelum inkubasi). Jika nilai absorbansi akhir (sesudah inkubasi) masing-masing tabung lebih besar dari nilai absorbansi awal (sebelum inkubasi) maka disimpulkan bahwa masih terjadi pertumbuhan bakteri. Namun jika sebaliknya tidak terdapat perubahan nilai absorbansi antara nilai absorbansi akhir dengan absorbansi awal atau nilai absorbansi akhir lebih kecil dari nilai absorbansi awal maka disimpulkan bahwa pertumbuhan bakteri terhambat. ${ }^{11,13,14}$

Setelah mengukur nilai kekeruhan pada masing-masing tabung perlakuan pertama, kedua, dan ketiga didapatkan bahwa konsentrasi $25 \%$ terjadi penghambatan pertumbuhan bakteri. Hal ini terbukti karena tidak terdapat perubahan nilai absorbansi sesudah dan sebelum inkubasi. Pada konsentrasi $100 \%$ terjadi penurunan nilai absorbansi yang artinya bakteri terhambat pada konsentrasi tersebut. Konsentrasi 50\% merupakan konsentrasi yang lebih tinggi dari konsentrasi $25 \%$ yang seharusnya dapat menghambat pertumbuhan bakteri. Kenaikan nilai absorbansi pada konsentrasi $50 \%$ tidak sepenuhnya karena pertumbuhan bakteri, tetapi diduga dipengaruhi oleh kepekatan konsentrasi yang terjadi pada konsentrasi yang lebih tinggi, sehingga dapat memengaruhi penyerapan cahaya oleh sel-sel bakteri yang mati di dalam larutan. ${ }^{13}$

Pada penelitian ini terjadi kenaikan nilai absorbansi kontrol negatif yang seharusnya turun atau tetap karena tidak diberikan perlakuan. Kenaikan ini disebabkan oleh faktor kelemahan alat spektrofotometer UV-Vis yaitu dalam selektivitas untuk membedakan sampel dengan partikel-partikel lain atau kontaminan yang menyerap cahaya dalam panjang gelombang yang sama. ${ }^{15.16}$ Kelemahan spektrofotometer UV-Vis dapat diminimalisiasi dengan menggunakan alat Kromatografi Cair Kinerja Tinggi (KCKT). Alat KCKT merupakan alat analisis kimia kuantitatif yang dapat melakukan pemisahan senyawa spesifik dan dapat mengukur jumlah senyawa di dalam larutan. ${ }^{14.17}$ Alat KCKT juga berfungsi sebagai pendeteksi senyawa dalam produk obat. ${ }^{18}$

\section{SIMPULAN}

Berdasarkan hasil penelitian dapat disimpulkan bahwa Konsentrasi Hambat Minimum (KHM) getah kulit buah pisang goroho (Musa acuminafe L.) terhadap pertumbuhan bakteri Staphylococcus aureus dengan menggunakan turbidimetri terdapat pada konsentrasi 50\% dan demgan menggunakan spektrofotometer UV-Vis terdapat pada konsentrasi $25 \%$.

\section{SARAN}

Perlu dilakukan penelitian lebih lanjut mengenai uji Konsentrasi Hambat Minimum getah kulit buah pisang goroho (Musa acuminafe L) terhadap pertumbuhan Staphylococcus aureus dengan menggunakan metode Kromatografi Cair Kinerja Tinggi (KCKT) untuk memperoleh hasil yang lebih akurat.

Diharapkan penelitian lebih lanjut untuk melakukan uji konsentrasi bunuh minimum (KBM) getah kulit buah pisang goroho (Musa acuminafe L) terhadap pertumbuhan Staphylococcus aureus.

\section{DAFTAR PUSTAKA}

1. Sariningsih E. Gigi Busuk dan Poket Periodontal sebagai Fokus Infeksi. Jakarta: PT Elex Media Komputindo, 2014; p. 26-8.

2. Shweta, Prakash SK. Dental abscess: A microbiological review. Dent Res J (Isfahan). 2013;10(5):585-91.

3. Gillespie SH, Bamford KB. At a Glance 
Mikrobiologi Medis dan Infeksi (3rd ed). Tania $\mathrm{SH}$, penerjemah. Jakarta: Erlangga, 2009.

4. Pelczar MJ, Chan ECS. Dasar-Dasar Mikrobiologi. Jakarta: UI-Press, 1998; p. 563.

5. Turang AC. Mengenal pisang goroho (Musa acuminafe, sp). [cited 2018 Feb 23]. Available from: http://sulut.litbang. deptan.go.id/ind/index.php?option=co m_content\&view=article\&id=189:men genal-pisang-goroho-musa acuminafesp\&catid=80:leaflet\&Itemid $=69$.

6. Rante BK, Assa YA, Gunawan PN. Uji daya hambat getah kulit buah pisang goroho(Musa acuminafe L) terhadap pertumbuhan Staphylococcus aureus. eG. 2017;5(2):130-4.

7. Juliana C, Edi S, Yudistira A. Analisis fitokimia dan uji aktivitas antioksidan dari getah kulit buah pisang goroho (Musa Acuminate (L.). Jurnal Ilmiah Farmasi Unsrat. 2013;2(3):34-9.

8. Winarsi H. Antioksidan Alami dan Radikal Bebas Potensi dan Aplikasinya dalam Kesehatan. Yogyakarta: Kanisius, 2007; p. 177.

9. Supriatna, Moelyono MW, Iskandar Y. Prinsip Obat Herbal. Yogyakarta: Budi Utama, 2014; p. 14-5.

10. Cockerel FR, Wikler MA, Alder J, Dudley MN, Eliopoulus GM, Ferraro GM. Methods for Dilution Antimicrobial Susceptibility Test for Bacteria that Grow Aerobically Approve (9th ed). USA: Clinical and Laboratory Standard Institute

11. Astutiningsih $C$, Setyani $S$, Hindratna $H$. Uji daya antibakteri dan identifikasi isolate senyawa katekin dari daun teh
(Camellia sinensis L. var Assamica). Jurnal Farmasi Sains dan Komunitas. 2014;11(2):50-7.

12. Michel C, Blanc G. Minimum Inhibitory Concentration Methodology in Aquaculture: The temperature. Aquacultur. 2001;196:311-8.

13. Kusuma DF. Aktivitas Antibakteri Ekstrak Etanol Buah Mengkudu (Morinda citrifolia Linnaeus) terhadap Bakteri Pembusuk Daging Segar. Pusat Informasi Ilmiah. Surakarta: Universitas Sebelas Maret, 2010; p. 33.

14. Septian K. Uji Konsentrasi Hambat Minimum (KHM) Ekstrak Spons Laut (Callyspongia sp.) terhadap partumbuhan bakteri Staphylococcus aureus. Manado. Dentire. 2016;5(1):5-10.

15. Permata DAA. Uji Konsentrasi Hambat Minimum (KHM) Ekstrak Daun Bombay (Allium cepa L) Terhadap Pertumbuhan Staphylococcus aureus. Manado. Pharmacon. 2014;5(4):52-9.

16. Geisler J, Thompson T, Choosing the best detection method: absorbance vs. fluorescence. [cited 2018 May 10]. Available from: https://www. biocompare.com/Bench-Tips/173963Choosing-the-Best-Detection-MethodAbsorbance-vs-Fluorescence

17. Watson GD. Analisis Farmasi: Buku Ajar untuk Mahasiswa Farmasi dan Praktisi Kimia. Jakarta: EGC, 2007; p.105-27.

18. Amalia KR, Sumantri, Ulfah M. Perbandingan metode spektrofotometer UV dan Kromatografi Cair Kinerja Tinggi (KCKT) pada penetapan kadar natrium diklofenak. Semarang: Fakultas Farmasi Universitas Wahid Hasyim Semarang; 2010. 